\title{
Grading Women's Clothing Patterns with the CAD Pattern System to Improve Student Learning Outcomes and Competencies
}

\author{
Umi Kulsum \\ Program Keahlian Tata Busana, SMK Negeri 5 Malang, Indonesia \\ E-mail: kulsum2406@gmail.com
}

A R T I C L E I N F O

Article history:

1 Maret 2020 Received in revised form

30 Maret 2020

Accepted 11 April 2020

Available online 15

Mei 2020

Kata Kunci:

CAD Pattern System,

grading, hasil belajar,

kompetensi

Keywords:

CAD Pattern System,

grading, learning outcomes,

competency

\begin{abstract}
A B S T R A K
Tujuan dari penelitian ini memperbaiki kualitas pembelajaran dengan meningkatkan hasil belajar dan kompetensi siswa membuat grading pola busana wanita menggunakan media pembelajaran CAD Pattern System. Rancangan penelitian ini adalah Penelitian Tindakan Kelas (Classroom Action Recearch). Penelitian ini dilakukan sebanyak dua siklus, pada setiap siklus terdiri dari empat tahapan yaitu perencanaan, pelaksanaan, observasi dan refleksi. Subjek dalam penelitian ini siswa kelas XI Tata Busana 1 SMK Negeri 5 Malang berjumlah 34 siswa. Pengumpulan data dengan tes, dan uji kinerja (unjuk kerja). Hasil penelitian menunjukkan terdapat peningkatan hasil belajar dan kompetensi siswa dalam membuat grading pola busana wanita. Dari aspek pengetahuan terjadi peningkatan skor rata-rata dari siklus I ke siklus II sebesar 17,0. Dari aspek keterampilan/kompetensi terjadi peningkatan skor rata-rata dari siklus I ke siklus II sebesar 1,03. Kesimpulan penelitian ini bahwa penggunaan media pembelajaran $C A D$ Pattern System sangat efektif, ditunjukkan dengan: (1) peningkatan hasil belajar siswa dalam membuat grading pola busana wanita, (2) peningkatan kompetensi siswa dalam membuat grading pola busana wanita, (3) CAD Pattern System ini diharapkan bisa dipergunakan sebagai media pembelajaran dalam mata palajaran Pembuatan Busana
\end{abstract}

\begin{abstract}
A B S T R A C T
The purpose of this study is to improve the quality of learning by improving student learning outcomes and competence in grading women's fashion patterns using the CAD Pattern System learning media. The design of this study is Classroom Action Research. This research was conducted in two cycles, in each cycle consisting of four stages, namely planning, implementation, observation, and reflection. The subjects in this study were students of grade XI Fashion 1 State Vocational School 5 Malang totaling 34 students. Data collection by tests, and performance tests (performance). The results showed an improvement in student learning outcomes and competence in grading women's fashion patterns. From the aspect of knowledge, an increase in the average score from cycle I to cycle II was 17.0. From the aspect of skills/competence, an increase in average score from cycle I to cycle II was 1.03. This study concludes that the use of the CAD Pattern System learning media is very effective, indicated by (1) improvement in student learning outcomes in making women's fashion patterns grading, (2) improvement of student learning competence in making women's fashion patterns grading, (3) CAD Pattern System is expected to be used as a learning medium in the subjects of Industrial Clothing Making, in pattern grading competencies fashion, but still pay attention to school conditions and the characteristics of students.
\end{abstract}

\section{Introduction}

Fashion pattern grading competence is one of the fashion patterns techniques, is part of the Industrial Clothing subjects. In the Syllabus of the Fashion Management expertise program at SMK Negeri 5 Malang, the distribution of fashion pattern grading competencies is presented during the even semester of grade XI. Grading fashion patterns at SMK Negeri 5 Malang is still applied conventionally. This method is less effective because, besides, to prepare a pattern book, students also have to prepare all the equipment to make a pattern. Such as the pattern ruler, scale ruler, and also stationery used to make patterns. Although every student is given a job sheet and the teacher has explained the steps in making grading patterns, but not all students can grading women's fashion patterns correctly. There are still some students who do not understand the learning material, it is shown by the large number of students who ask their teachers and their friends who are considered more understanding. This situation makes the class noisy and not conducive.

Based on the results of a preliminary study conducted in grade XI Tata Busana 1 obtained data on learning outcomes and student competence in grading women's fashion patterns in the subjects of Industrial Clothing, in general, is still low. From 34 students known the average score was 68.7. This score had not yet reached the KKM because the KKM score for the Indonesian Clothing Making subject was 75.0. Based on the results of these observations shows that several problems inhibit learning to make women's fashion pattern 
grading. Students do not fully understand the concept of grading. The low ability of some students to solve problems that have an impact on learning outcomes.

When viewed from the time allocation, the subjects of Industrial Clothing (grading women's clothing patterns) for the face-to-face time provided are classified as insufficient. Duration of time $4 \times 45$ minutes for the delivery of material, application of competencies, and assignments can not include the objectives in the lesson plan. This results in students' assignments not being completed properly, and students must continue their work at home as homework. Because of the competency in grading women's clothing patterns, they are still done manually, so that in addition to a long time, the results of women's fashion patterns are also less than the maximum. This makes students not competent in grading women's fashion patterns.

This condition needs to be improved to make optimal quality in learning. We need an effort from the teacher who is considered the most appropriate way to improve student competency in grading women's fashion patterns. Learning media need to support the learning process, to facilitate the teacher in delivering the material so it is easy for students to understand. Arsyad (2016) stated that the benefits of learning media are as follows: (1) delivery of lessons becomes more standard; (2) learning can be more interesting; (3) learning becomes more interactive, so students are more active in class; (4) learning time can be shortened; (5) the quality of learning outcomes can be improved; (6) the teacher's role can change in the more positive direction, and reduce the possibility of repeating explanations over and over. Likewise in this study, the use of instructional media can improve the achievement of learning outcomes and student competencies

The conventional use of instructional media in competencies in grading women's fashion patterns certainly not able to accommodate learning goals, so new learning media need to be used with computerization / digital with the CAD Pattern System. In this study, with the use of the CAD Pattern System, teachers could demonstrate and could be followed by students. Students actively follow the direction and guidance of the teacher, so that there are no more students who are passive or have difficulties. Learning runs smoothly and the classroom atmosphere becomes conducive.

Computer-Aided Design (CAD) is a design system using computer equipment and software with a specific design, which allows users to plan, model, evaluate a product/item accurately before it is produced. With CAD applications as computer software, making clothing patterns will be faster and easier. Muhdhor (2018) stated that the use of CAD applications in modern society has entered almost every industry including the fashion design industry. Following the demands of the current digital era, many fashion education institutions integrate the use of CAD in the teaching curriculum.

Vocational education is a part of the education system that prepares a person to be better able to work in one occupational group or one particular occupation (Damarjati, 2016). Characteristics of vocational education aside from being directed to be ready to enter the workforce, it is also emphasized on the mastery of knowledge, skills, attitudes, and values needed by the world of work. Vocational High School (SMK) is one of the educational institutions that are responsible for creating human resources that have the ability, skills, and expertise so that graduates can develop performance when engaged in the working world.

Clothing Management Vocational School is one of the Vocational Schools which is inseparable from the goals that want to prepare graduates to be ready to take part in the business and industrial world. Therefore it is necessary to synchronize learning programs in schools within the industry. Dandira (2017) argues that synchronization is needed to achieve learning programs in schools and industry. Furthermore, Hadijah (2018) stated that Fashion Management SMK is urgently needed in the fashion industry, such as in the field of ability/competency in making fashion patterns, fashion pattern grading, both manually and computerized. The qualifications needed in the fashion industry: (a) Vocational School Fashion Management, (b) understanding fashion patterns, and (c) mastering software for markers.

To realize the fulfillment of quality human resources in the field of fashion, required graduates who can compete in facing challenges and achieving success in the fashion industry. By mastering CAD technology, students of Fashion Design SMK become superior and highly competitive human resources so that they are ready to play a role and compete in the global fashion business. From an article, professional human resources in a fashion not only required to be able to operate computers only in the production of documents but also able to use computers to produce computer-based creative works from the design process to produce clothing products (Fitrihana, 2016). One effort to make it happen is by applying the use of the CAD Pattern System as a media in making grading women's clothing patterns.

Grading in the field of clothing can be interpreted as an example of the design of existing fashion patterns, then adjust it again according to a certain size level. So grading fashion patterns is the process of enlarging or shrinking a pattern into another pattern with different size from the original pattern but with the same model. The advantage of pattern grading is that it speeds up the process of making a series of patterns of different sizes thereby increasing time, energy, and cost-efficiency. Pattern grading techniques can be done manually or by computerized / digital. This concept as stated by Mullet (2015) about the concept of grading 
patterns, namely techniques for manual and computer grading. For grading by computerized / digital, you can use CAD (Computer-Aided Design) Pattern System.

The use of CAD Pattern Systems in learning to make grading for women's clothing patterns is not only aimed at increasing student competency. Through automated CAD grading and making technology, clothing patterns are more accurate and the percentage of material usage is more efficient. This is because errors in the process of making grading can be minimized so that the result of fashion pattern grading is more effective. As stated by Kiliç (2019) the results of his research show that the time taken to create a pattern with a CAD system is shorter / more efficient than the manual method. Making patterns with computer media is more efficient because the accuracy of the size of the pattern is more accurate. Zulfikar (2017) that making patterns on garments with a computer system the results are more efficient with pattern markers that minimize waste / residual pieces of fabric.

Increasing the competency of students in grading women's fashion patterns, the use of the CAD Pattern System media is an effort to improve student learning outcomes in grading women's fashion patterns. Learning outcomes are the most important part of learning. Student learning outcomes are essentially changes in behavior that includes cognitive, affective, and psychomotor fields. Learning outcomes can indicate the level of success of a person after doing the learning process in changes and developments. Sudjana (2016) learning outcomes are abilities possessed by students after participating in learning. Learning outcomes are a peak of the learning process. Susanto (2015) stated that student learning outcomes are abilities obtained by children after going through learning activities.

Based on the above problems, the purpose of this study is to improve the quality of learning by (1) improving student learning outcomes in grading women's fashion patterns using the CAD Pattern System; (2) increase student competency in grading women's fashion patterns by using the CAD Pattern System

\section{Method}

The research design used was Classroom Action Research. According to Arikunto \& Suhardjono (2015), classroom action research (CAR) is an observation in the form of actions against learning activities that are deliberately raised and occur in a classroom. This CAR was chosen using the spiral model of Kemmis \& Taggart. Broadly speaking in action research there are four stages in each step (1) planning, (2) action, (3) observation, and (4) reflection. The four stages are stages to form a cycle, which is a round of successive activities that return to the original step. So, one cycle is the stage of preparing a plan or design to the stage of reflection. Classroom Action Research (CAR) is action research that aims to improve the quality of learning in the classroom.

In this study, it was conducted at SMK Negeri 5 Malang, located on Jalan Piranha Atas Malang, East Java. The subjects chosen in this study were students of grade XI Tata Busana 1 SMK Negeri 5 Malang in 2019/2020 academic year, with 34 students. Meanwhile, the subject was the Production of Industrial Clothing Patterns on the Grading Women's Clothing Patterns. The data was collected by knowledge tests, and performance tests (performance). Knowledge tests are used to find out the cognitive aspects that students have. While the performance test (performance) is used to determine the abilities and skills/competencies of students.

Cognitive aspects were measured using a written test at the end of the cycle in the form of multiplechoice questions. From the psychomotor aspect measured using performance tests (performance), the skills/competencies of students in making grading women's clothing patterns. Performance appraisal is an assessment that asks students to demonstrate knowledge and skills that produce a particular product or performance. In this study performance tests (work samples) were carried out with computer/laptop media and other assistive devices that purpose was to determine the ability and competence of students in grading women's fashion patterns using the CAD Pattern System.

\section{Result and Discussion}

After the application of learning to grade women's fashion patterns using the CAD, Pattern System was implemented, data was obtained about learning outcomes and student competencies. From the aspect of knowledge, the results of the acquisition of scores can be presented in the following table 1 and table 2.

Table 1. Frequency and Percentage of Knowledge Score in Cycle I

\begin{tabular}{cccc}
\hline No & Score & Frequency & Percentage $(\%)$ \\
\hline 1. & 80 & 4 & 11,765 \\
2. & 77 & 15 & 44,118 \\
3. & 75 & 12 & 35,294 \\
4. & 70 & 3 & 8,823 \\
\hline
\end{tabular}

Average: $\quad 75.5$ 
The highest frequency score obtained by students was 80 , who get this score was 4 or $11.765 \%$ of students. While the least frequency score of 70 was 3 or $8.823 \%$ of students.

Table 2. Frequency and Percentage of Knowledge Scores in Cycle II

\begin{tabular}{cccc}
\hline No & Score & Frequency & Percentage $(\%)$ \\
\hline 1. & 100 & 5 & 14,706 \\
2. & 95 & 10 & 29,412 \\
3. & 90 & 12 & 35,294 \\
4. & 85 & 7 & 20,588 \\
\hline Average & 92.5 & 34 & 100 \\
\hline
\end{tabular}

The biggest score is 100 obtained by 5 students with $14.706 \%$. While the lowest score of 85 was obtained by 7 students or $20,588 \%$. Comparison of the knowledge average score obtained in cycle I and cycle II illustrated in the following diagram.

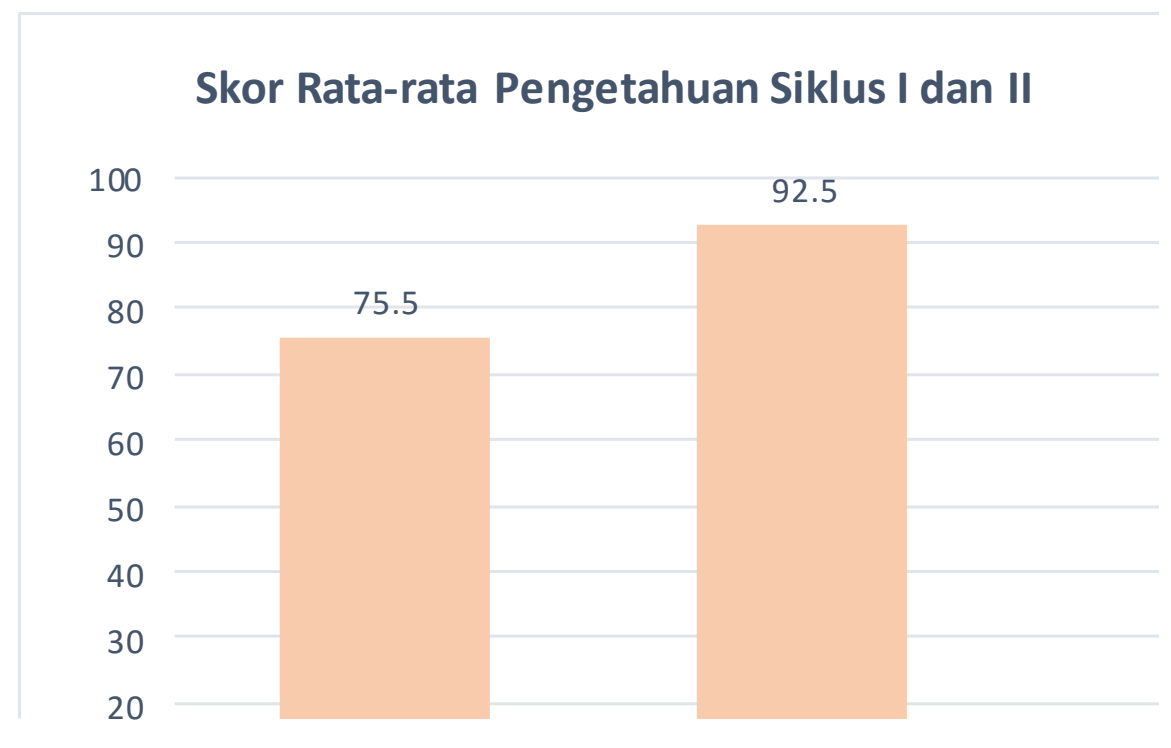

Figure 1

Comparison of average scores of knowledge scores in cycle I and cycle II table 4 .

From the aspect of students' skills/competencies, the results can be presented in the following table 3 and

Table 3. Frequency and Percentage of Skills / Competency Scores in Cycle I

\begin{tabular}{|c|c|c|c|}
\hline No & Score & Frequency & Percentage $(\%)$ \\
\hline 1 & 8,5 & 2 & 5,882 \\
\hline 2 & 8,3 & 3 & 8,824 \\
\hline 3 & 8,0 & 5 & 14,706 \\
\hline 4 & 7,7 & 6 & 17,647 \\
\hline 5 & 7,5 & 8 & 23,529 \\
\hline 6 & 7,2 & 7 & 20,588 \\
\hline 7 & 7,0 & 3 & 8,824 \\
\hline Average & 7,74 & 34 & 100 \\
\hline
\end{tabular}


Table 4. Frequency and Percentage of Skills / Competency Scores in Cycle II

\begin{tabular}{cccc}
\hline No & Score & Frequency & Percentage (\%) \\
\hline 1 & 9,4 & 1 & 2,941 \\
2 & 9,2 & 2 & 5,882 \\
3 & 9,0 & 7 & 20,588 \\
4 & 8,8 & 13 & 38,235 \\
5 & 8,6 & 8 & 23,530 \\
6 & 8,4 & 3 & 8,823 \\
\hline Average & 8,77 & 34 & 100 \\
\hline
\end{tabular}
diagram

Comparison of the average score of skills obtained in cycle I and cycle II illustrated in the following

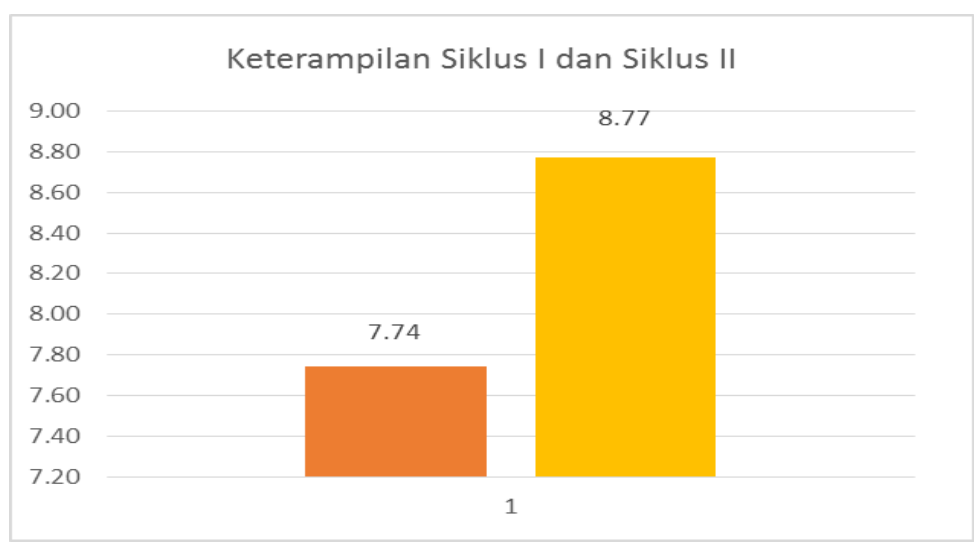

Figure 2

Comparison of average skills/competencies scores in cycle I and cycle II

The application of the use of learning media CAD Pattern System in making grading of women's clothing patterns conducted by the teacher is following the implementation plan. Based on observations made by observers, the implementation of learning in the first cycle was in a good category. Whereas in the second cycle the implementation of learning was in a very good category.

From the knowledge aspect, in the first cycle, the highest score obtained by students was 80 and the lowest was 70. In the second cycle, the highest score obtained by students was 100 and the lowest was 85 . There was an increase in scores, for the highest score from 80 to 100 and the lowest from 70 to 85 . If calculated on average, in the first cycle an average score was 75.5 and in the second cycle, an average score was 92.5. The average score increase was 17.0. From the aspect of skills/competencies, in the first cycle, the highest score obtained by students was 8.5 and the lowest score was 7.0. In the second cycle, the highest score obtained by students was 9.4 and the lowest was 8.4. An increase in score, the highest score from 8.5 to 9.4, and the lowest score from 7.0 to 8.4 . In the first cycle, the largest percentage of average skills/competencies was 8.5 , with a frequency was 2 or $5.882 \%$ students.

The scores obtained from the lowest average skills/competencies were 7.0 were obtained by 3 students $8.824 \%$. In cycle II, the biggest skill score was 9.4 , it was obtained by 1 student or $2,941 \%$. While the lowest skill score was 8.4 was obtained by 3 or $8.823 \%$ of students. If calculated on average, in cycle I an average score was 7.74 and in cycle II an average score was 8.77. Thus an increase in average score was 1.03

The results of the explanation above show that the use of the CAD Pattern System media can improve student learning outcomes in terms of knowledge. One contributing factor is that the teacher makes improvements to the learning process following the reflection activities in the previous cycle. Another factor that causes an increase in cognitive domain learning outcomes is the application of the use of the CAD Pattern System media in learning that can form new knowledge so that students' understanding of women's fashion pattern grading material with the CAD Pattern System media is deeper. Likewise from the psychomotor aspect, the use of the CAD Pattern System media can improve students' skills/competencies in grading women's fashion patterns. Through the mastery of in-depth material, students can apply psychomotor through practical activities well, this can be demonstrated by the activeness of students in participating in learning.

CAD learning not only teaches students about the application of what feature commands are used but also teaches how to use CAD to solve problems in the design and drawing process (Wahyu, 2013). According to Ye Xiuz (2004: 152), some important things need to be given in CAD learning. First, the ability to formulate 
engineering problem solving is the ability used to analyze problems using several questions such as the effort you want to do draftsmen? How to make this easy for draftsmen? Second, the ability to use computers to solve problems is an emphasis on students' ability to apply computers to solve problems (eg mechanics) and how to let go of the solutions to the problems they face. Third, the ability to practice independently (the most important thing) is to practice the use of CAD directly even in a small domain (eg simple assembly with 3 parts).

CAD competency according to Dollan (2011: 6-13) can be obtained from the Autodesk Inventor certification material itself. The competencies in question are User Interface, File Management, Sketches, Parts, Assemblies, Drawings, Presentations, Sheet metal, Visualization. From these competencies, there are some basic competencies that students must understand in practicing CAD including parts competencies (components), assemblies (drawings), and drawings (work drawings).

CAD supports the learning process and improved pattern making competency. This is supported by several research results. (1) Sukmawati (2019) the research aims to test the stages of the training model of fashion pattern making using a CAD system to improve the competence of teachers in vocational high schools. The results of the study show that the training model of fashion pattern making using a CAD system is very good and meets the requirements of validity, effectiveness, and practicality. (2) Suryani et al. increased the knowledge and competence to make fashion patterns. Performance/competency tests obtained an average score was 79.2. Training positive response $91.67 \%$, training material positive response $97.95 \%$, and a positive response to the training module $97.15 \%$

The development of CAD is also demonstrated by the method and grading pattern making. Supporting research results as demonstrated by Stainley \& Bayter (2016) by developing methods and grading for computeraided pattern making to help students apply the concepts of manual grading and CAD grading. The results of the study recommend grading computer-aided patterns (CAD) to better understand differences in clothing size and grading these patterns for future class projects. Furthermore, Dewi (2019) aimed her research to study the need for teaching materials that need to be developed in the Fashion Pattern Grading course using the CAD patternmaking program. The results of the study indicate that it is necessary to develop teaching materials for grading that can facilitate students to learn either face-to-face or independently.

The development of CAD has greatly helped the industry in competition in the current era of globalization. The use of CAD Pattern System media will cover the whole process of making grading and can be accommodated quickly and cheaply. This is because errors in the process of making grading can be minimized and have implications for reducing time so that it is more efficient, and the results of grading women's clothing patterns more effectively. The benefits of using CAD technology in the fashion industry include: (1) accelerating the realization of creative ideas of a designer; (2) there is no need to manually make it repeatedly from sketching, coloring to creating a finished product; (3) able to be reproduced quickly; (4) digital files are more durable; (5) saving storage space.

The garment industry is growing rapidly with new concepts so that the fashion business is maintained. As noted by Tabraz (2017) in the fashion industry innovations with computer-aided design (CAD) systems are needed to meet market demand. With the CAD industry can quickly do the design process, the results can be directly seen in 3D illustrations that almost resemble a real form. Furthermore, Papachristou (2019) showed that CAD could be for the development of making garment prototypes from ten different fashion design patterns.

Singh \& Singh (2017) argue about the development of CAD for manufacturing clothing patterns, providing several advantages, in addition to increasing production speed, also increasing accuracy and precision in production. Likewise shown by Ejeimi (2020) in his experimental research aimed at exploring the feasibility of clothing for industrial production by grading patterns using the digital ZWD (Zero Waste Design) method which can be simulated in 3D. ZWD method is a design method for making clothes without waste or using materials according to the design. The results showed that the adjustment of pattern cuts on the grading and layout of the markers reached $100 \%$ efficiency and accurate visual display of ZWD appreciation.

\section{Conclusion}

From the results of research and data analysis, it can be concluded that the use of the CAD Pattern System learning media is very effective, it can be demonstrated by the increase in scores and competencies obtained by students on each indicator, (1) from the aspects of learning outcomes/aspects of knowledge, (2) from the aspect of skills/competencies of students in making grading for women's clothing patterns (3) CAD Pattern System is expected to be used as a medium in learning Industrial Clothing Making in fashion pattern grading competencies, while still paying attention to school conditions and student characteristics.

\section{References}

Arikunto, S. \& Suhardjono, S. 2015. Penelitian Tindakan Kelas Edisi Revisi. Jakarta: Bumi Aksara.

Arsyad, A. 2016. Media Pembelajaran Jakarta: Raja Grafindo Persada. 
Damarjati, Taufik. 2016. Konsep Pembelajaran di Sekolah Menengah Kejuruan. Direktorat Jenderal Pendidikan Dasar dan Menengah Kementerian Pendidikan dan Kebudayaan.

Dandira, T., Maphosa, C., Nsubuga, Y., 2017, Students' workplace learning experiences: How do Clothing Fashion Design Students Apply Knowledge and Skills Gained at University to the Workplace? Journal of Hospitality, Tourism and Leisure, Volume 6 (1) - (2017) ISSN : 2223 - 814X Copyright: (C) 2017 AJHTL Open Acces - Online@ https//: www.ajhtl.com 1.

Dewi, S. N., \& Nelmira, W. 2019. Analisis Kebutuhan Pengembangan Bahan Ajar Grading Pola Busana Menggunakan Program Cad Pattern Making Mahasiswa Tata Busana Jurusan Ikk Fpp Unp. The International Journal of Public Policy Management and Administration, 1(1), 58-67.

Ejeimi, S. 2020. Grading Zero Waste Design using Digital and Virtual Methods (Doctoral dissertation). krex.kstate.edu (K- State Research Exchange).

Fitrihana, N. 2016. Urgensi Literasi Komputer pada Pembelajaran di SMK Tata Busana untuk Menyiapkan Generasi Emas Indonesia. Prosiding Pendidikan Teknik Boga Busana, 11(1).

Hadijah,I.dkk. 2018. Kompetensi Pembuatan Pola Busana Berbasis CAD Pattern System Guru SMK Tata Busana di Malang Raya. Jurnal KARINOV,Vol.1 No 2, Mei 2018.

KiliÇ, A. 2019. Comparison of Cad and Manual System Efficiency In Pre-Production Preparation Process. Journal of Textil \& Apparel /TEKSTIL VE KONFEKSIYON, 29(1), 73-84.

Muhdhor, 2018. Pattern, Grading dan Marker Design CAD Richpeace. Kementerian Pendidikan dan Kebudayaan Direktorat Jenderal Pendidikan.

Mullet, K. K. 2015. Concepts of pattern grading: Techniques for manual and computer grading. Bloomsbury Publishing USA.

Papachristou, E., Kyratsis, P., Bilalis, N. 2019. A Comparative Study of Open-Source and Licensed CAD Software to Support Garment Development Learning, Journal 2019 7(2),30; https://DOI.org/10.3390/machines7020030, accessed on 29 January 2020.

Singh, S., \& Singh, R. 2017. Development of a CAD Tool for Pattern Making of Garments. International Journal of Innovative Computer Science \& Engineering, 4(2), 11 - 15.

Sudjana, Nana. 2016. Penilaian Hasil Proses Belajar Mengajar. Bandung: PT Remaja Roesdakarya.

Sukmawati, S. 2019. Development of Training Model for Fashion Making Patterns Using CAD (ComputerAided Design) System to Improve Teacher's Competencies at SMK Majoring in Fashion in Gowa District (Doctoral dissertation, Pascasarjana).

Suryani, H., Imayanti, I., \& Yahya, M. 2018, July. The Effectiveness of Clothing Pattern Making Training with CAD-based System on Fashion Students. In International Conference on Indonesian Technical Vocational Education and Association (APTEKINDO 2018). Atlantis Press.

Susanto, A. 2015. Teori Belajar Dan Pembelajaran Disekolah Dasar. Jakarta: Prenada.

Stanley, A. E., \& Baytar, F. 2016. "Implementing Pattern Grading in a Computer-Aided Patternmaking Course: Developing Materials and Utilizing Learning Tools". International Textile and Association (ITAA). Annual Conference Proceedings ISSN 2572-679X.

Tabraz, M. 2017. Importance Of Fashion Cad (Computer-Aided Design) Study For Garment Industry In Bangladesh. Internatıonal Journal Of Scientific\& Technology Research, 6.

Wahyu, Aden. 2013. Upaya Meningkatkan Kompetensi Siswa Dalam Mata Diklat CAD Melalui Metode Pembelajatan Peer Teaching di SMK Negeri 2 Depok, Sleman Yogyakarta. Skripsi. FT-UNY

Ye, Xiuzi. et. al. (2004). Today's Student, Tomorrow's Engineers: an Industrial Perspective on CAD Education. Computer-Aided Design International Journal. Vol. 36. Elsevier

Zulfikar, H. M. 2017. Effect of Garment Size Ratio and Marker Width Variation on Marker Efficiency for both Manual and Computerized Marker. European Journal of Advances in Engineering and Technology, 4(10), 765-772. 